\title{
Analisis Peranan Tim Pengendalian Inflasi Daerah Terhadap Perekonomian Dumai
}

\author{
Soni Fajar Mahmud \\ Program Studi Teknik Industri, Sekolah Tinggi Teknologi Dumai \\ Jl. Utama Karya Bukit Batrem II \\ Email: sfajarmahmud@gmail.com
}

\begin{abstract}
ABSTRAK
Saat ini Kota Dumai terus menggeliat maju dari yang pada awalnya hanya merupakan sebuah dusun kecil, kini telah menjadi kota Jasa, Perdagangan Industri dan Pariwisata, serta salah satu penyumbang pendapatan negara melalui sektor pelabuhan. Inflasi bisa diakibatkan oleh kebijakan-kebijakan yang diambil oleh pemerintah. Suatu inflasi tidak boleh terlalu besar (hyper inflation) karena dapat mengakibatkan daya beli masyarakat turun dan tidak boleh terlalu rendah karena akan melemahkan daya saing. Penelitian ini mengkaji tentang bagaimana peranan Tim Pemantauan dan Pengendalian Inflasi Daerah (TPID) terhadap inflasi di Kota Dumai. Penelitian ini dibagi menjadi dua bagian, yang pertama untuk melihat bagaimana pergerakan inflasi di Kota Dumai sebelum dan sesudah adanya TPID, dan yang kedua adalah untuk melihat bagaimana persistensi inflasi di Kota Dumai. Penelitian ini adalah penelitian deskriptif kuantitatif. Hasil dari penelitian ini adalah peran tim pengendalian inflasi daerah adalah mengevaluasi sumber-sumber dan potensi tekanan inflasi serta dampaknya terhadap pencapaian target inflasi, dan melakukan pemantauan terhadap pelaksanaan kebijakan yang ditempuh dalam rangka pengendalian inflasi sehingga dapat meningkatkan daya beli dan menghambat laju pertumbuhan penduduk miskin di Kota Dumai.
\end{abstract}

Kata kunci: Industri, Inflasi, Sembako,

\begin{abstract}
Currently the City of Dumai continues to stretch forward from what was originally only a small village, has now become the city of Services, Industry and Tourism Trade, and one of the contributors to state revenue through the port sector. Inflation can be caused by policies taken by the government. An inflation cannot be too large (hyper inflation) because it can cause the purchasing power of the people to go down and not be too low because it will weaken competitiveness. This study examines the role of the Regional Inflation Monitoring and Control Team (TPID) on inflation in Dumai City. This type of research is quantitative descriptive research. Then this research is divided into two parts, the first one is to see how inflation moves in Dumai City before and after the TPID, and the second is to see how inflation persistence in Dumai City. The results of this study are the Role of the Regional Inflation Control Team is evaluating the sources and potential of inflationary pressures and their impact on achieving the inflation target, and monitoring the implementation of
\end{abstract}


policies adopted in order to control inflation. Thus, it can increase purchasing power and inhibit the growth rate of poor people in Dumai City.

Keywords: Industry, Inflation, Basic needs,

\section{Pendahuluan}

Kota Dumai merupakan salah satu kota di Provinsi Riau yang berada di pesisir pantai pulau Sumatera sebelah timur. Posisi Dumai juga berdekatan dengan beberapa negara asing diantaranya Singapura dan Malaysia. Ini menjadi suatu keunggulan dan keuntungan yang bersifat komparatif dibanding daerah lain terutama di Provinsi Riau. Posisi yang strategis ini sangat mendukung untuk kegiatan ekspor produk dalam negeri dan impor produk asing. Peluang lain yang mungkin adalah terciptanya suatu kawasan perdagangan bebas antar negara di Kota Dumai. Saat ini Kota Dumai terus menggeliat maju dari yang pada awalnya hanya merupakan sebuah dusun kecil, kini telah menjadi kota Jasa, Perdagangan Industri dan Pariwisata, serta salah satu penyumbang pendapatan negara melalui sektor kepelabuhanan. Filosofi dasar peningkatan status pengelolaan wilayah administrasi pemerintahan adalah untuk memperpendek rentang kendali dan mempercepat tingkat pelayanan serta meperbesar peran serta masyarakat dalam penyelenggaraan pemerintahan, pengelolaan ekonomi yang sangat menjanjikan.

Perekonomian di suatu daerah dipengaruhi oleh beberapa faktor. Salah satu faktornya yaitu Inflasi. Inflasi adalah suatu kenaikan harga-harga. Inflasi bisa diakibatkan oleh kebijakan-kebijakan yang diambil oleh pemerintah. Suatu inflasi tidak boleh terlalu besar (hyper inflation) karena dapat mengakibatkan daya beli masyarakat turun dan tidak boleh terlalu rendah karena akan melemahkan daya saing. Perekonomian disuatu daerah dapat dikatakan baik apabila kebijakankebijakan yang diambil oleh pemerintahnya bisa mengendalikan inflasi. Perkembangan ekonomi di Dumai saat ini mengalami naik turun terutama pada permasalahan harga pokok dan sembako. Menurut BPS Kota Dumai $(2017,04)$ terhitung dari bulan Januari 2017 sampai dengan bulan Maret 2017, telah terjadi inflasi sebesar 1,35 persen dan deflasi sebesar 0,19 persen. Untuk menyikapi semua permasalahan itu maka Pemerintah Kota Dumai membentuk Tim Pengendalian Inflasi Daerah yang berperan membantu menjaga stabilitas perekonomian di daerah dan mengatasi permasalahan ekonomi sektor riil serta menjaga stabilitas harga barang dan jasa yang terjangkau oleh masyarakat.

\section{Metode Penelitian}

Jenis Penelitian ini adalah penelitian deskriptif kuantitatif. Menurut Mudrajat Kuncoro, 2009, penelitian deskriptif merupakan pengumpulan data untuk

UNITEX Vol 11 No.1 Januari - Juni 2018 | p-ISSN 2089-3957 | e-ISSN 2580-2585 
diuji hipotesis atau menjawab pertanyaan mengenai status terakhir dari subjek penelitian. Penelitian ini mengkaji tentang bagaimana peranan Tim Pemantauan dan Pengendalian Inflasi Daerah (TPID) terhadap inflasi di Kota Dumai. Kemudian penelitian ini dibagi menjadi dua bagian, yang pertama untuk melihat bagaimana pergerakan inflasi di Kota Dumai sebelum dan sesudah adanya TPID, dan yang kedua adalah untuk melihat bagaimana persistensi inflasi di Kotya Dumai.

\section{Hasil dan Pembahasan}

Inisiatif pembentukan TPID dimulai sejak 2008 dengan dukungan dari berbagai kalangan, khususnya di daerah. Saat ini telah terbentuk 93 TPID di 33 provinsi yang mencerminkan semakin tingginya kesadaran daerah terhadap implikasi inflasi bagi kegiatan pembangunan dan untuk kesejahteraan masyarakat secara umum. Keberadaan TPID juga menekankan pentingnya kerangka kerjasama yang lebih bersinergi antar daerah sejalan dengan implementasi Rencana Pembangunan Jangka Menengah Nasional (RPJMN). Besarnya komitmen daerah untuk turut berpartisipasi menjaga stabilitas harga tertuang dalam hasil Rapat Koordinasi Nasional (Rakornas) II TPID yang diselenggarakan pada 16 April 2011. Pada Rakornas II TPID juga disepakati pembentukan Kelompok Kerja Nasional (Pokjanas) TPID yang beranggotakan Bank Indonesia (BI), Kementerian Koordinator Bidang Perekonomian (Kemenko), dan Kementerian Dalam Negeri (Kemendagri) melalui penandatanganan Nota Kesepahaman (MoU) Nomor. MOU01/M.EKON/03/2011, 13/I/GBI/DKM/NK, 300-194 Tahun 2011.

Sebagai tindak lanjut dari MoU tersebut, pada penyelenggaraan Rapat Koordinasi Wilayah (Rakorwil) TPID Jakarta-Jabar-Banten tanggal 14 Juli 2011 ditandatangani Perjanjian Kerjasama (PKS) antara ketiga pihak tersebut yang menandai terbentuknya Pokjanas TPID. Pembentukan TPID juga didasarkan pada Surat Keputusan Bersama (SKB) Menteri Keuangan No.88/KMK.02/2005 dan Gubernur Bank Indonesia No.7/9/KEP.GBI/2005 yang berlaku untuk masa tugas 1 tahun (tahun 2005). Untuk selanjutnya, dasar hukum pelaksanaan tugas TPID diatur dalam Surat Keputusan (SK) Menteri Keuangan (Menkeu) yang ditetapkan setiap tahun. TPID dibentuk berdasarkan pertimbangan bahwa inflasi yang rendah dan stabil merupakan satu sasaran yang ingin dicapai Pemerintah, sebagai bagian dalam upaya menjaga stabilitas makro ekonomi sesuai dengan Rencana Pembangunan Jangka Menengah (RPJM) dan Undang-Undang (UU) Nomor 23 Tahun 1999 tentang Bank Indonesia sebagaimana telah diubah terakhir dengan Undang-Undang Nomor 6 Tahun 2009.

Bulan Maret 2017, Kota Dumai mengalami deflasi sebesar 0,19 persen dengan Indeks Harga Konsumen (IHK) sebesar 124,23. Laju inflasi tahun kalender (Maret 2017 terhadap Desember 2016) sebesar 2,52 persen dan laju inflasi "year on year" (Maret 2017 terhadap Maret 2016) sebesar 5,33 persen. Deflasi di Dumai terjadi karena adanya penurunan indeks harga pada beberapa kelompok pengeluaran yaitu

UNITEX Vol 11 No.1 Januari - Juni 2018 | p-ISSN 2089-3957 | e-ISSN 2580-2585 
kelompok bahan makanan sebesar 1,35 persen, diikuti kelompok transpor, komunikasi dan jasa keuangan mengalami penurunan indeks sebesar 0,08 persen, kelompok sandang sebesar 0,01 persen. Sedangkan peningkatan indeks harga juga terjadi pada beberapa kelompok yaitu kelompok pendidikan, rekreasi dan olahraga sebesar 0,05 persen, kelompok kesehatan sebesar 0,07 persen, kelompok makanan jadi, minuman, rokok dan tembakau sebesar 0,24 persen serta kelompok perumahan, air, listrik, gas \& bahan bakar sebesar 0,62 persen.

Komoditas yang memberikan andil terbesar terjadinya deflasi di Kota Dumai antara lain bayam, kangkung, tongkol/ambu-ambu, tarip pulsa ponsel, telur ayam ras, daging sapi, cabai rawit, daun singkong, tomat buah, udang basah, kembung/gembung/banyar/gembolo/aso-aso, jeruk, cabai merah, ayam hidup, minyak goreng dan cumi-cumi.

Dari 23 kota di Sumatera yang menghitung IHK, 15 (lima belas) kota mengalami deflasi dengan deflasi tertinggi terjadi di Tanjung Pandan sebesar 1,49 persen, Lhoksumawe sebesar 1,40 persen, Batam sebesar 0,83 persen, Sibolga sebesar 0,70 persen; Tanjung Pinang sebesar 0,64 persen; Padangsidimpuan sebesar 0,43 persen; Metro sebesar 0,30 persen; Medan sebesar 0,20 persen, Dumai sebesar 0,19 persen dan deflasi terendah di Padang sebear 0,01 persen. Dari sepuluh ibukota provinsi di Sumatera, 6 (enam) ibukota provinsi mengalami deflasi dengan deflasi tertinggi terjadi Pangkal Pinang sebesar 0,64 persen, Medan sebesar 0,20 persen, Banda Aceh sebesar 0,15 persen, Palembang sebesar 0,10, Bandar Lampung sebesar 0,06 persen, Padang sebesar 0,01 persen dan 4 (empat) kota mengalami inflasi dengan inflasi tertinggi di Bengkulu sebesar 0,23 persen dan terendah di Pekanbaru dan Pangkal Pinang sebesar 0,38 persen.

Berdasarkan hasil pemantauan oleh BPS Kota Dumai, bulan Maret 2017, Kota Dumai mengalami deflasi sebesar 0,19 persen dengan Indeks Harga Konsumen (IHK) sebesar 130,85. Laju inflasii tahun kalender (Maret 2017 terhadap Desember 2016) sebesar 2,52 persen dan laju inflasi "year on year" Maret 2017 terhadap Maret 2016) sebesar 5,33 persen. Deflasi di Dumai terjadi karena adanya penurunan indeks harga pada beberapa kelompok pengeluaran yaitu kelompok bahan makanan sebesar 1,35 persen, diikuti kelompok transpor, komunikasi dan jasa keuangan mengalami penurunan indeks sebesar 0,08 persen serta kelompok sandang sebesar 0,01 persen.

Tabel 1. Tabel Inflasi Kota Dumai Maret 2017, Tahun Kalender dan Year on Year 2016

\begin{tabular}{|c|c|c|c|c|c|}
\hline $\begin{array}{c}\text { Kelompok } \\
\text { Pengeluaran }\end{array}$ & $\begin{array}{c}\text { IHK } \\
\text { Maret } \\
2017\end{array}$ & $\begin{array}{c}\text { IHK } \\
\text { Desember } \\
2016\end{array}$ & $\begin{array}{c}\text { \%erububahan } \\
\text { erhadap } \\
\text { Februari } \\
2017\end{array}$ & $\begin{array}{c}\text { Laju } \\
\text { Inflasi } \\
\text { Tahun } \\
\text { Kalender }\end{array}$ & $\begin{array}{c}\text { Inflasi } \\
\text { Tahun ke } \\
\text { Tahun }\end{array}$ \\
\hline 1 & 2 & 3 & 4 & 5 & 6 \\
\hline Umum & 124.23 & 127.63 & -0.19 & 2.52 & 5.33 \\
\hline
\end{tabular}




\begin{tabular}{|l|c|c|c|c|c|}
$\begin{array}{l}\text { 1. Bahan } \\
\text { Makanan }\end{array}$ & 127.82 & 133.75 & -1.35 & 3.46 & 8.26 \\
\hline $\begin{array}{l}\text { 2. Makanan jadi, } \\
\text { minuman, rokok, } \\
\text { dan tembakau }\end{array}$ & 133.5 & 140.51 & 0.24 & 1.25 & 6.57 \\
\hline $\begin{array}{l}\text { 3. Perumahan, } \\
\text { air, listrik, gas, } \\
\text { dan bahan bakar }\end{array}$ & 199.62 & 121.64 & 0.62 & 3.41 & 5.16 \\
\hline $\begin{array}{l}\text { 4. Sandang } \\
\text { 5. Kesehatan }\end{array}$ & 118.66 & 119.45 & 0.07 & 2.62 & 3.30 \\
\hline $\begin{array}{l}\text { 6. Pendidikan, } \\
\text { rekreasi, dan } \\
\text { olahraga }\end{array}$ & 119.21 & 119.93 & 0.05 & -0.18 & 0.42 \\
\hline $\begin{array}{l}\text { 7. Transpor, } \\
\text { komunikasi, dan } \\
\text { jasa keuangan }\end{array}$ & 118.78 & 118.51 & -0.08 & 3.13 & 2.90 \\
\hline
\end{tabular}

Sumber: BPS Kota Dumai 2017

Keterangan:

1. Kolom 4 Persentase perubahan IHK bulan Maret 2017 terhadap IHK bulan Februari 2017

2. Kolom 5 Persentase perubahan IHK bulan Maret 2017 terhadap IHK bulan Desember 2016

3. Kolom 6 Persentase perubahan IHK bulan Maret 2017 terhadap IHK bulan Maret 2016

Jika dibandingkan setiap tabel dari bulan Januari 2017 sampai dengan Maret 2017, kelompok pengeluaran yang memiliki andil besar dalam meningkatnya inflasi di Kota Dumai yaitu kelompok makanan jadi, minuman, rokok dan tembakau, dan kelompok transportasi, komunikasi, dan jasa keuangan. Tetapi pada bulan Maret 2017, tingkat inflasi tidak terlalu tinggi. 
Tabel 2. Tabel andil inflasi/deflasi menurut kelompok pengeluaran kota Dumai, maret 2017

\begin{tabular}{|l|c|}
\multicolumn{1}{|c|}{ Kelompok Pengeluaran } & $\begin{array}{c}\text { Andil Inflasi/ } \\
\text { Deflasi (\%) }\end{array}$ \\
\hline \multicolumn{1}{|c|}{1} & 2 \\
\hline Umum & -0.19 \\
\hline 1. Bahan Makanan & -0.36 \\
\hline 2. Makanan jadi, minuman, rokok, dan tembakau & 0.05 \\
\hline 3. Perumahan, air, listrik, gas, dan bahan bakar & 0.13 \\
\hline 4. Sandang & 0.00 \\
\hline 5. Kesehatan & 0.00 \\
\hline 6. Pendidikan, rekreasi, dan olahraga & 0.00 \\
\hline 7. Transpor, komunikasi, dan jasa keuangan & -0.01 \\
\hline
\end{tabular}

Kelompok komoditas yang memberikan andil/sumbangan deflasi adalah kelompok bahan makanan sebesar 0,36 persen, diikuti kelompok kelompok transpor, komunikasi dan jasa keuangan 0,01 persen. Terdapat 2 kelompok yang memberikan andil/sumbangan inflasi yaitu kelompok perumahan, air, listrik, gas dan bahan bakar sebesar 0,13 persen serta kelompok makanan jadi, minuman, rokok dan tembakau sebesar 0,05 persen. Sedangkan kelompok sandang, kesehatan dan pendidikan serta rekreasi dan olah raga tidak memeberkan andil terhadap inflasi/deflasi di Kota Dumai karena harga relatif stabil.

\section{Bahan Makanan}

Pada bulan Maret 2017, kelompok bahan makanan mengalami deflasi sebesar 1,35 persen atau terjadi penurunan indeks harga dari 140,27 pada Februari 2017 menjadi 138,38 pada Maret 2017. Laju inflasi tahun kalender (Maret 2017 terhadap Desember 2016) sebesar 3,46 persen dan laju inflasi Year on Year (Maret 2017 terhadap Maret 2016) sebesar 8,26 persen. Dari sebelas sub kelompok dalam kelompok bahan makanan 7 (tujuh) sub kelompok mengalami deflasi dengan deflasi tertinggi terjadi pada sub kelompok sayur-sayuran sebesar 13,94 persen, diikuti sub kelompok buah-buahan sebesar 1,53 persen, sub kelompok daging dan hasil-hasilnya sebesar 1,33, sub kelompok telur, susu, dan hasil-hasilnya sebesar 0,80, sub kelompok bahan makanan lainnya sebesar 0,48 persen, sub kelompok padi-padian, umbi-umbian dan hasilnya sebesar 0,07 persen, sub kelompok ikan segar sebesar 0,05 persen. Sedangkan ada 4 (empat) sub kelompok yang mengalami inflasi dengan inflasi tertinggi terjadi pada sub kelompok bumbu-bumbuan sebesar 2,86 persen, sub kelompok lemak dan minyak sebesar 0,50 persen, sub kelompok ikan diawetkan sebesar 0,27 dan sub kelompok kacang-kacangan sebesar 0,24 persen.

Kelompok bahan makanan pada Maret 2017 memberikan sumbangan/andil deflasi sebesar 0,36 persen terhadap total deflasi Kota Dumai dengan Komoditas yang memberikan andil terbesar terjadinya deflasi di Kota Dumai antara lain: kangkung, tongkol/ambu-ambu sebesar 0,08 persen, telur ayam ras dan daging sapi sebesar 0,04 persen, cabai rawit dan daun singkong sebesar 0,03 persen, udang basah, kembung/gembung/banyar/gembolo/asoaso dan jeruk sebesar 0,02 persen, 
cabai merah, ayam hidup minyak goreng dan cumi-cumi sebesar 0,01 persen dan lain sebagainya. Komoditas yang memberikan andil terbesar terjadinya inflasi di Kota Dumai antara lain: bawang merah sebesar 0,11 persen, serai sebesar 0,06 persen, Nila sebesar 0,03 persen, kelapa sebesar 0,02 persen, kentang, gabus, daun seledri, caru, daun bawang, ketimun, wortel, senangin, susu untuk balita sebesar 0,01 persen.

\section{Makanan Jadi, Minuman, Rokok \& Tembakau}

Kelompok Makanan Jadi, Minuman, Rokok dan Tembakau pada Maret 2017 mengalami inflasi sebesar 0,24 persen atau terjadi peningkatan indeks dari 141,93 pada pada Februari 2017 menjadi 142,27 pada Maret 2017. Laju inflasi tahun kalender (Maret 2017 terhadap Desember 2016) sebesar 1,25 persen dan laju inflasi Year on Year (Maret 2017 terhadap Maret 2016) sebesar 6,57 persen. Dari 3 (tiga) sub kelompok dalam kelompok ini, inflasi tertinggi terjadi pada sub kelompok minuman yang tidak beralkohol sebesar 0,62 persen, diikuti sub kelompok tembakau dan minuman beralkohol sebesar 0,31 persen dan sub kelompok makanan jadi sebesar 0,05 persen.

Kelompok makanan jadi, minuman, rokok dan tembakau pada bulan Maret 2017 memberikan sumbangan/andil inflasi sebesar 0,05 persen terhadap total deflasi/inflasi Kota Dumai. Komoditas yang memberikan andil terbesar terjadinya inflasi di Kota Dumai antara lain komoditas air kemasan sebesar 0,02 persen, kopi bubuk dan rokok kretek sebesar 0,01 persen, sedangkan komoditas lain relatif stabil.

\section{Perumahan, Air, Listrik, Gas \& Bahan Bakar}

Kelompok Perumahan, Air, Listrik, Gas dan Bahan Bakar pada bulan Maret 2017 mengalami inflasi sebesar 0,62 persen atau terjadi peningkatan indeks harga dari 125,01 pada Februari 2017 menjadi 125,79 pada Maret 2017. Laju inflasi tahun kalender (Maret 2017 terhadap Desember 2016) sebesar 3,41 persen dan laju inflasi Year on Year (Maret 2017 terhadap Maret 2016) sebesar 5,16 persen. Dari 4 (empat) sub kelompok dalam kelompok ini, inflasi tertinggi terjadi pada sub kelompok bahan bakar penerangan dan air sebesar 1,83 persen, dikuti sub kelompok perlengkapan rumah tangga sebesar 0,62 persen, sub kelompok penyelenggaraan rumah tangga sebesar 0,16 persen dan sub kelompok biaya tempat tinggal sebesar 0,03 persen. Pada Maret 2017, kelompok perumahan, air, listrik, gas dan bahan bakar memberikan sumbangan/andil inflasi sebesar 0,13 persen dengan komoditas penyumbang inflasi terbesar adalah tarif dasar listrik sebesar 0,11 persen dan lain sebagainya.

\section{Sandang}

Kelompok Sandang pada Maret 2017 mengalami deflasi sebesar 0,01 persen, atau terjadi penurunan indeks harga dari 124,44 pada Februari 2017 menjadi 124,43 persen pada Maret 2017. Laju inflasi tahun kalender (Maret 2017 terhadap Desember 2016) sebesar 1,13 persen dan laju inflasi Year on Year (Maret 2017 terhadap Maret 2016) sebesar 2,65 persen. Dari 4 (empat) sub kelompok dalam kelompok ini, 1 (satu) sub kelompok mengalami deflasi yaitu sub kelompok barang pribadi dan sandang lain sebesar 0,21 persen, sedangkan 2 (dua) sub kelompok

UNITEX Vol 11 No.1 Januari - Juni 2018 p-ISSN 2089-3957 | e-ISSN 2580-2585 
mengalami inflasi dengan inflasi tertinggi terjadi pada sub kelompok sandang wanita sebesar 0,09 persen diikuti sub kelompok sandang laki-laki sebesar 0,01 persen. Sementara itu sub kelompok sandang anak-anak relatif stabil. Pada Maret 2017 kelompok sandang tidak mengalami perubahan yg signifikan sehingga angka inflasi/deflasi relatif stabil.

\section{Kesehatan}

Kelompok Kesehatan pada bulan Maret 2017 mengalami mengalami inflasi sebesar 0,07 persen atau terjadi peningkatan indeks dari 122,49 pada Februari 2017menjadi 122,58 pada Maret 2017. Laju inflasi tahun kalender (Maret 2017 terhadap Desember 2016) sebesar 2,62 persen. Laju inflasi Year on Year (Maret 2017 terhadap Maret 2016) sebesar 3,30 persen. Dari 4 (empat) sub kelompok dalam kelompok ini, inflasi tertinggi terjadi pada sub kelompok obat-obatan sebesar 0,32 ; diikuti sub kelompok jasa kesehatan sebesar 0,03 persen; sub kelompok perawatan jasmani dan kosmetika sebesar 0,02 persen sedangkan sub kelompok jasa perawatan jasmani relatif stabil. Pada Maret 2017, andil komoditas dalam kelompok kesehatan relatif stabil.

\section{Pendidikan, Rekreasi, dan Olahraga}

Kelompok pendidikan, rekreasi dan olah raga pada bulan Maret 2017 mengalami inflasi sebesar 0,05 persen atau terjadi peningkatan indeks dari 119,65 pada Februari 2017 menjadi 119,71 pada Maret 2017. Laju inflasi tahun kalender (Maret 2017 terhadap Desember 2016) sebesar -0,18 persen (deflasi) dan laju inflasi Year on Year (Februari 2017 terhadap Februari 2016) sebesar 0,42 persen. Dari 5 (lima) sub kelompok dalam kelompok ini, 1 (satu) sub kelompok mengalami inflasi yaitu sub kelompok perlengkapan/peralatan pendidikan sebesar 0,27 persen, sedangkan sub kelompok lainnya relatif stabil. Pada Maret 2017, andil komoditas dalam kelompok Pendidikan, Rekreasi dan Olahraga relatif stabil.

\section{Transpor, Komunikasi dan Jasa Keuangan}

Kelompok Transpor, Komunikasi dan Jasa Keuangan pada bulan Maret 2017 mengalami deflasi sebesar 0,08 persen atau terjadi penurunan indeks dari122,32 pada Februari 2017 menjadi 122,22 pada Maret 2017. Laju inflasi tahun kalender (Maret 2017 terhadap Desember 2016) sebesar 3,13 persen dan laju inflasi Year on Year (Maret 2017 terhadap Maret 2016) sebesar 2,90 persen. Dari 4 (empat) sub kelompok dalam kelompok ini, 1(satu) sub kelompok yang mengalami deflasi yaitu sub kelompok komunikasi dan pengiriman sebesar 1,26 persen, sedangkan 2 (dua) sub kelompok lainnya mengalami inflasi dengan inflasi tertinggi pada sub kelompok kelompok sarana dan penunjang transpor sebesar 0,54 persen diikuiti sub kelompok transpor sebesar 0,27 persen. Sub kelompok jasa keuangan relatif stabil.

Pada Maret 2017 kelompok transpor, komunikasi dan jasa keuangan memberikan sumbangan/andil deflasi sebesar 0,01 persen terhadap total deflasi Kota Dumai dengan komoditas penyumbang deflasi yakni tarif pulsa ponsel sebesar 0,06 persen. Komoditas penyumbang inflasi adalah angkutan antar kota, mobil, sepeda motor, telepon seluler, helm, cuci kendaraan masing-masing sebesar 0,01 persen, sedangkan komoditas lain relatif stabil. Tim Pengendalian Inflasi Daerah Kota

UNITEX Vol 11 No.1 Januari - Juni 2018 p-ISSN 2089-3957 | e-ISSN 2580-2585 
Dumai setiap tahunnya menyusun kerangka kegiatan yang akan mendukung jalannya proses pelaksanaan monitoring dan evaluasi terkait harga bahan pokok dan barang penting lainnya. Untuk itu TPID membuat sebuah Roadmap Pengendalian Inflasi Kota Dumai.

Roadmap Pengendalian Inflasi Kota Dumai merupakan kerangka kerja dan acuan dalam penyusunan program kerja jangka pendek dan menengah TPID Kota Dumai. Untuk mewujudkan upaya pengendalian inflasi daerah ini diperlukan komitmen dari seluruh SKPD terkait di Kota Dumai, yaitu Dinas Perindustrian dan Perdagangan dan Dinas Pertanian bidang Ketahanan Pangan. Tujuan dari program kerja TPID Kota Dumai adalah stabilisasi dan penurunan disparitas harga dan ketersediaan bahan pokok masyarakat didaerah, sehingga tersedianya bahan pokok dan daya beli masyarakat terjangkau. Selain itu, tujuan program kerja TPID juga untuk melaksanakan peran aktif Pemerintah Kota Dumai dalam Pengendalian Inflasi sehingga dapat meningkatkan daya beli dan menghambat laju pertumbuhan penduduk miskin di Kota Dumai.

Sasaran dari program TPID Kota Dumai adalah pengendalian sistem distribusi bahan pokok dan barang penting serta tersedianya informasi/data yang akurat tentang harga, stok dan pasokan bahan pokok dan penting. Selain itu perlu adanya program pasar murah secara berkala khususnya pada momen Hari Besar Keagamaan Nasional guna pengendalian stabilisasi harga. Serta peningkatan produksi bahan pangan untuk pengendalian biaya pengeluaran rumah tangga dengan pemanfaatan lahan pekarangan rumah. TPID diharapkan dapat mengevaluasi sumber-sumber dan potensi tekanan inflasi di Kota Dumai serta dampaknya terhadap pencapaian sasaran inflasi daerah. Dapat menyampaikan informasi kebijakan yang telah dilakukan dan rencana kebijakan oleh instansiinstansi terkait kepada dewan pengarah, serta melaksanakan diseminasi mengenai sasaran dan upaya pencapaian sasaran inflasi kepada masyarakat.

Berdasarkan data dari Bank Indonesia Perwakilan Propinsi Riau, secara umum perkembangan harga barang dan jasa di Propinsi Riau pada Bulan Januari 2017 mengalami peningkatan dengan tingkat inflasi 1,46\%, lebih tinggi dibandingkan inflasi Desember 2016 yang tercatat 0,23\% dan inflasi nasional yang sebesar $0,97 \%$. Secara spesial, inflasi bulanan tertinggi di Kota Dumai yaitu sebesar 1,58\%, diikuti Kota Pekanbaru sebesar 1,46\%, dan Tembilahan sebesar 1,19\%. Secara Tahunan, realisasi inflasi Riau sebesar 5,21\%.

\section{Simpulan}

Tim Pengendalian Inflasi Daerah adalah Kelompok Kerja Nasional (Pokjanas) yang dibentuk oleh Pemerintah Pusat setelah mempertimbangkan bahwa inflasi yang rendah dan stabil merupakan satu sasaran yang ingin dicapai Pemerintah, sebagai bagian dari upaya menjaga stabilitas makro ekonomi yang sesuai dengan Rencana Pembangunan Jangka Panjang yang telah dirancang oleh Pemerintan. 
Proses kerja Tim Pengendalian Inflasi Daerah yaitu pertama adanya instruksi dari Presiden, lalu diteruskan kepada setiap Kementerian yang terkait dan Kantor Perwakilan Bank Indonesia yang memegang peranan penting dalam menjaga kestabilan inflasi. Selanjutnya, dari Bank Indonesia menginstruksikan kepada setiap Kepala Daerah, untuk Kota Dumai diteruskan kepada Walikota Dumai yang kemudian dilanjutkan kepada Kepala Bagian Administrasi Perekonomian Setda Kota Dumai. Pada tahap ini, Administrasi Perekonomian hanya memfasilitasi dan memonitoring/mengawasi setiap kegiatan yang dijalankan, dan untuk mencapai setiap sasaran yang telah direncanakan diperlukan kerja sama dengan dinas-dinas yang terkait. Peran Tim Pengendalian Inflasi Daerah adalah mengevaluasi sumbersumber dan potensi tekanan inflasi serta dampaknya terhadap pencapaian target inflasi, dan melakukan pemantauan terhadap pelaksanaan kebijakan yang ditempuh dalam rangka pengendalian inflasi. Sehingga, dapat meningkatkan daya beli dan menghambat laju pertumbuhan penduduk miskin di Kota Dumai.

\section{Daftar Pustaka}

Bernane. (2009). Teori Makro Ekonomi (4th), Alih Bahasa Imam Nurmawan. Erlangga. Jakarta.

BPS. (2000). Dumai Dalam Angka: Dumai Municipality in Figures. BPS Kota Dumai. Dumai

Eachern. (2000). Ekonomi Makro: Pendekatan Kontemporer. Salemba Empat. Jakarta.

Judisseno. (2005). Perpajakan (Edisi Revisi). Gramedia Pustaka Utama. Jakarta.

Khan. (2006). Anggaran Pemerintah dan Inflasi Indonesia. Gramedia. Jakarta.

Mankiw. (2003). Principles of Macroeconomics. United States of Amerika Worth Publisher.

Maski. (2007). Perekonomian Indonesia. Jakarta: Galia Indonesia.

Mulyani. (1996). Akuntansi Syariah di Indonesia. Jakarta: Salemba Empat.

Nopirin. (2005). Ekonomi Moneter (Buku Satu). Yogyakarta: BPFE.

Nopirin. (2011). Ekonomi Moneter (Buku Dua). Yogyakarta: BPFE.

Prasetyo. (2011). Pengantar Ekonomi Makro. Yogyakarta: BPFE.

Putong. (2002). Pengantar Ekonomi Makro dan MikroJakarta: Mitra Wacana Media.

Sukirno. (2004). Makroekonomi: Teori Pengantar. Jakarta: PT Raja Grafindo Persada. 